\title{
Influence of Cell Size on the Effects of Insulin and Noradrenaline on Human Adipose Tissue
}

\author{
B. Jacobsson, G. Holm, P. Björntorp and U. Smith \\ Clinical Metabolic Laboratory of the Depts. of Medicine I and II, Univ. of Gothenburg, Sahlgren's Hospital, Gothenburg, Sweden
}

\begin{abstract}
Summary. In the present study dose-response relationships of the effects of noradrenaline and insulin on fat cells of different sizes were performed. Adipose cells larger than $100 \mu \mathrm{m}$ were more responsive (expressed as absolute effects) to the lipolytic action of noradrenaline as well as to the antilipolytic effect of insulin. This suggests that in the larger cells the capaci$t y$, i. e. the sum of factors contributing to the ability to stimulate or inhibit the metabolic rates, was greater than in the smaller ones. In contrast the sensitivity to these agents, i.e. the readiness to respond, was not different between small and large cells.

It is shown that the concentrations of insulin needed to obtain an antilipolytic effect is far below that needed to stimulate glucose incorporation. This discrepancy in insulin concentrations required may be due to binding of insulin to receptors with different affinity.
\end{abstract}

Key words: Human adipose tissue, lipolysis, noradrenaline, insulin.

It is now well established that fat cell size is of importance for the cellular responsiveness to certain hormones. In human adipose tissue it has been shown that the lipolytic effect of catecholamines is enhanced in large fat cells [1-4]. Furthermore, data have been presented indicating that the antilipolytic action of insulin is more pronounced in large cells as well $[2,5]$. However, fairly high concentrations of catecholamine and insulin have generally been used for the studies. Thus the results show that the metabolic capacity, i.e. the sum of factors contributing to the ability to stimulate or inhibit the metabolic rates, is increased in large fat cells. In order to analyse the cellular sensitivity to these hormones, which well may be a physiologically more relevant parameter, dose-response relationships have to be analysed.

In the present study different concentrations of insulin and noradrenaline were used and the sensitivity for these agents was analysed in fat cells below or above $100 \mu \mathrm{m}$.

\section{Materials and Methods}

Specimens of subcutaneous adipose tissue were obtained from patients operated upon for an isolated abdominal disorder, generally cholelithiasis. Patients with jaundice, malignant or endocrine disorders were excluded. In the studies of the effect of catecholamine tissue biopsies were obtained in local field block anesthesia with $2 \%$ lidocain (Xylocain, ASTRA, Södertälje, Sweden) by incision in the lower lateral quadrant of the abdominal wall. Care was taken not to infiltrate the tissue biopsy with the anesthetic agent, since such agents inhibit lipolysis $[6,7]$. The biopsies were immediately placed in medium 199 and smaller specimens, weighing about $25-50 \mathrm{mg}$ each, were then prepared.

The incubation procedure has been described in detail previously [2]. Briefly, after preincubation for $30 \mathrm{~min}$ [8] the tissue specimens were incubated for 2 hours at pH 7.4 in $2.0 \mathrm{ml}$ medium 199 (Statens Bakteriologiska Laboratorium, Stockholm, Sweden) modified to a glucose concentration of $1.0 \mathrm{mM}$ and containing $40 \mathrm{mg} / \mathrm{ml}$ albumin (Fraction V, Sigma Chemical Co., St. Louis, Mo.). Noradrenaline (ASTRA AB, Södertälje, Sweden) and glucagonpoor insulin (Vitrum AB, Stockholm, Sweden) were added as indicated. The release of glycerol was taken as an index of the lipolysis and determined enzymatically [9]. For reasons previously discussed [10] the 


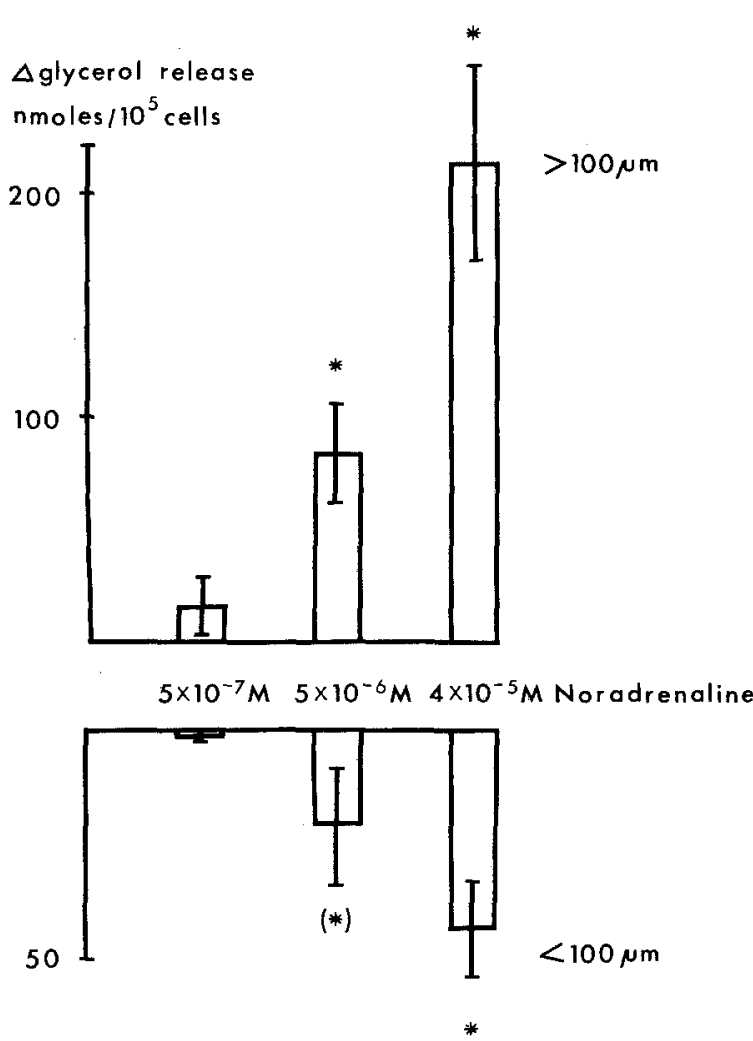

Fig. 1. The lipolytic effect of different concentrations of noradrenaline on fat cells above $(n=9)$ or below $(n=8) 100 \mu \mathrm{m} . \mathrm{N}=$ number of donors. * indicates significant lipolytic effect of noradrenaline $(p<0.05),\left(^{*}\right)$ indicates $0.05<p<0.1$. The basal lipolysis has been subtracted from both groups. Results \pm SEM

glycerol release was expressed in terms of the cellularity of the tissue specimens.

Mean cell diameter was determined on cells isolated with collagenase as previously described [11]. Mean cellular volume was calculated as suggested by Goldrick [12]. Mean cell weight was calculated according to Hirsch \& Gallian [13]. The tissue triglyceride content was analysed in the chloroform phase [14], as described by Carlson [15]. When the triglyceride content and mean cellular weight are known the number of fat cells of the specimens can be determined.

The results were analysed in relation to cell sizes larger and smaller than $100 \mu \mathrm{m}$. The mean \pm SEM for cells larger than $100 \mu \mathrm{m}$ was $105.35 \pm 1.70$ and for cells smaller than $100 \mu \mathrm{m} 90.0 \pm 2.5$. The difference was statistically significant $(p<0.001)$.

The ages of the donors were similar and the average for the group with the larger cell size was 52.4 years and for the group with the smaller cells 49.3 years.

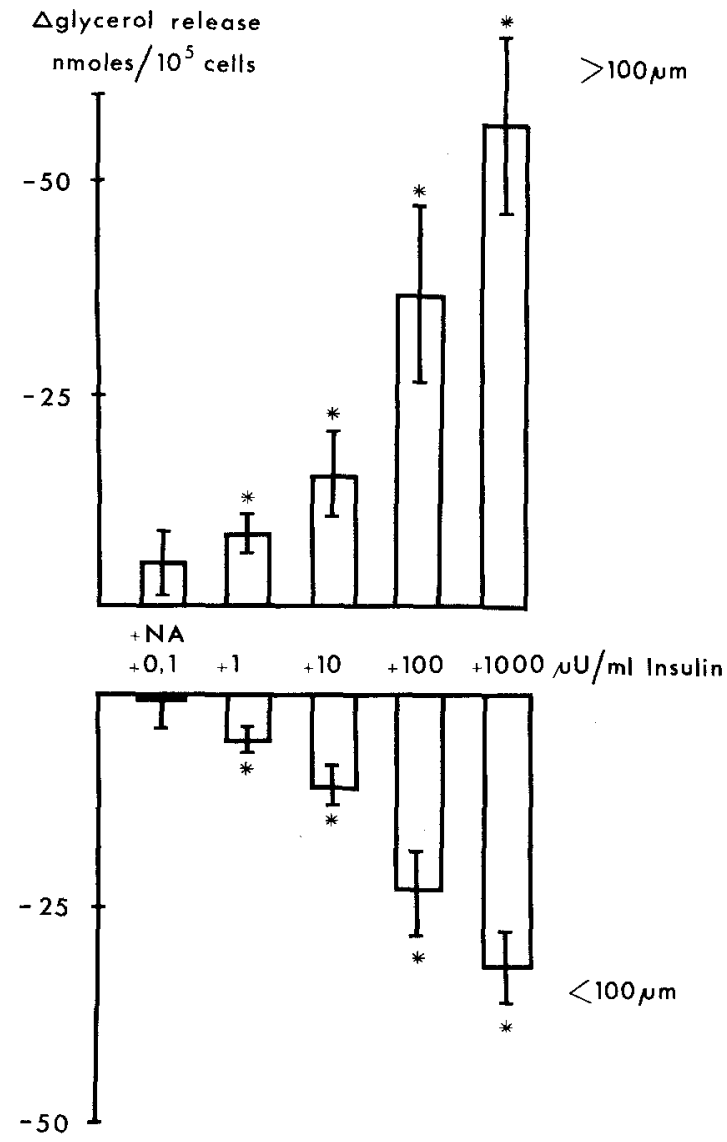

Fig. 2. The antilipolytic effect of different concentrations of insulin on the noradrenaline-stimulated lipolysis $\left(5 \times 10^{-5} \mathrm{M}\right)$ in fat cells above or below $100 \mu \mathrm{m}$. * indicates significant antilipolytic effect of insulin $(p<0.05)$. The number of donors, $n=10$ in both groups. Results \pm SEM

\section{Results}

\section{Noradrenaline-Stimulated Lipolysis}

The lipolytic effect of noradrenaline was enhanced in large fat cells. However, in both groups a consistent effect was found at $5 \times 10^{-6} \mathrm{M}$ (Fig. 1) and the concentration required for half-maximal effect was similar in both groups (about $10^{-5} \mathrm{M}$ ).

\section{Antilipolytic Effect of Insulin}

Previous experiments have shown that in these intact specimens a maximal lipolytic effect of noradrenaline was obtained with $4 \times 10^{-5} \mathrm{M}$ and for the antilipolytic action of insulin $1000 \mu \mathrm{U} / \mathrm{ml}$ was required [2].

The antilipolytic effect of insulin on the noradrenaline-stimulated lipolysis was analysed in two groups, i.e. specimens with a mean cell size above or below $100 \mu \mathrm{m}$. As shown in Fig. 2 the absolute effect of insulin on the lipolysis was, at all tested concentra- 
tions, more pronounced in the large cells. On a percentage basis, however, no difference was found between the two groups (Fig. 3). Furthermore, irrespective of fat cell size, a significant antilipolytic effect was found in these intact tissue specimens at $1.0 \mu \mathrm{U} / \mathrm{ml}$ and half-maximal effect was exerted in both groups at about $30 \mu \mathrm{U} / \mathrm{ml}$. These findings were not influenced by an effect of insulin on the basal lipolysis since in the presence of glucose it was inconsistent and variable (see below).

In Table 1 the effect of insulin at different concentrations on glucose metabolism is shown. The re-

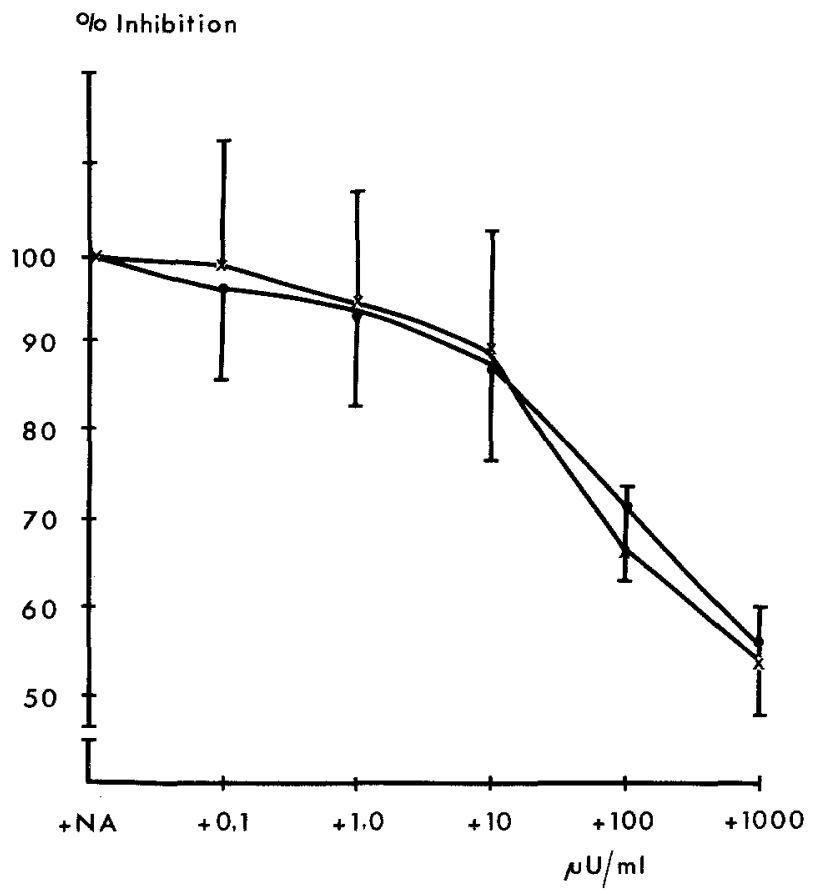

Fig. 3. The antilipolytic effect of different concentrations of insulin on the noradrenaline-stimulated lipolysis $\left(5 \times 10^{-5} \mathrm{M}\right)$. The results are expressed as percent of the lipolysis obtained in the absence of insulin $(=100 \%) . N=10$ in both groups. Results \pm SEM

Table 1. The effect of different concentrations of insulin on glucose metabolism in human fat cells

\begin{tabular}{cl}
\hline $\begin{array}{l}\text { Insulin concentration } \\
\mu \mathrm{U} / \mathrm{ml}\end{array}$ & $\begin{array}{l}\text { Incorporation of glucose } \\
\text { nmoles } / 10^{5} \text { cells }\end{array}$ \\
\hline 0 & 6.81 .0 \\
0.1 & 6.01 .1 \\
1.0 & 6.31 .3 \\
10 & 7.01 .0 \\
100 & $8.71 .5^{\mathrm{a}}$ \\
1000 & $9.41 .4^{\mathrm{a}}$ \\
\hline
\end{tabular}

Explants were incubated for $2 \mathrm{hrs}$ with $0.15 \mu \mathrm{Ci}\left[1-{ }^{14} \mathrm{C}\right]$ glucose. The incorporation into the total lipids was determined. $\mathrm{n}=5$. All specimens had a mean cell size larger than $95 \mu \mathrm{m}$.

${ }^{a}$ indicates significant increase over basal values $(p<0.05)$. sults indicate that the insulin effect on glucose disposal is obtained at higher concentrations than the effects exerted on lipolysis.

\section{Discussion}

It is now quite clear that the effect of certain hormones is more pronounced in large fat cells. However, since high hormone concentrations generally have been used it is not clear whether the sensitivity to hormones may differ between small and large cells.

The present data show that the lipolytic effect of noradrenaline as well as the antilipolytic action of insulin on catecholamine-stimulated lipolysis were more pronounced in large fat cells at all concentrations tested. This implies that the cellular metabolic capacity is increased in large fat cells. However, the cellular sensitivity, determined from the dose-response relationships, was similar in large and small cells. The findings of similar sensitivity to noradrenaline is in agreement with a reportbyGries et al. [16] where fat cells from obese and non obese individuals were compared.

Since glucose was used in the incubation medium the effect of insulin on the basal lipolysis was inconsistent, as also previously reported by several investigators $[2,17,18]$. In contrast to the present and other studies [2, 3, 5] Gries [19] reported that large fat cells were less responsive than small cells to the antilipolytic effect of insulin. The reason for this discrepancy is unclear but may be due to methodological differences. For instance 'in Gries' [19] study no glucose was present in the incubation medium and a lower catecholamine concentration was used.

The fact that large fat cells are as sensitive as small cells to the antilipolytic effect of insulin seems at variance with the effect of the hormone on glucose metabolism. It has been shown that there is a negative correlation between adipocyte size and the stimulatory effect of insulin on glucose metabolism [20,21]. Since this tissue resistance has by some investigators [22], but not all [23], been attributed to a diminished number of insulin receptors the present results may at first seem difficult to reconcile with this concept. However, several explanations are possible. It has, for instance, been suggested that there are different types of insulin receptors [24] in the cell membrane. Some support for this concept is offered by the findings that there are two populations of insulin receptors in the cell membrane; high affinity and low affinity receptors $[26,27]$. Furthermore, it may well be that a smaller portion of the total number of insulin receptors have to be occupied to elicit an antilipolytic response as compared to that required for the effect on glucose 
metabolism. The antilipolytic action requires $10-100$ times less insulin than that needed for the effect on glucose metabolism both in rat adipocytes [25] and in human fat cells (Table 1 ), which may support such a concept. It may well be then, that binding of insulin to the high affinity receptors initiates the antilipolytic effect while the low affinity receptors are mainly concerned with glucose metabolism.

The reason for the increased metabolic capacity in the large fat cells is unclear at present. It has been suggested that the number of receptors for catecholamines increases as the cells enlarge [28]. However, in analogy with the discussion above it seems likely that the cellular sensitivity should have been increased rather than only the metabolic capacity. Although several other possibilities may be considered the observation that large fat cells are more responsive to dibutyryl cAMP $[4,16]$ indicates that the triglyceride lipase may be increased in these cells.

Irrespective of the mechanism involved the present data clearly show the importance of performing dose-response curves, since an increased metabolic capacity cannot be extrapolated to imply an increased cellular sensitivity.

Acknowledgements. This study was supported by grants from the Swedish Medical Research Council (B75-19X-3506), Nordisk Insulinfond and the University of Gothenburg.

\section{References}

1. Faulhaber, J. D., Petruzzi, E. N., Eble, H., Ditschuneit, H.: In-vitro Untersuchungen über den Fettstoffwechsel isolierter menschlicher Fettzellen in Abhängigkeit von der Zellgröße: Die durch Adrenalin induzierte Lipolyse. Horm. Metab. Res. 1, 80-86 (1969)

2. Jacobsson, B., Smith, U.: Effect of cell size on lipolysis and antilipolytic action of insulin in human fat cells. J. Lipid Res. 3, 651-656 (1972)

3. Knittle, J. L., Ginsburg-Fellner, F.: Effect of weight reduction on in vitro adipose tissue lipolysis and cellularity in obese adolescents and adults. Diabetes 21, 754-761 (1972)

4. Óstman, J., Backman, L., Hallberg, D.: Cell size and lipolysis by human subcutaneous adipose tissue. Acta med. scand. 193, 469-475 (1973)

5. Östman, J., Backman, L., Hallberg, D.: Cell size and the antilipolytic effect of insulin in human subcutaneous adipose tissue. Diabetologia 11, 159-164 (1975)

6. Arner, P., Arner, O., Óstman, J.: The effect of local anaesthetic agents on lipolysis by human adipose tissue. Life Sciences 13, 161-169 (1973)

7. Kissebah, A. H., Clarke, P., Vydelingum, N., Hope-Gill, H., Tulloch, B., Fraser, T. R.: The role of calcium in insulin action. III. Calcium distribution in fat cells; Its kinetics and the effects of adrenaline and procaine-HCl. Europ. J. clin. Invest. 5, 339-349 (1975)

8. Óstman, J.: A procedure for in vitro studies on fatty acid metabolism by human subcutaneous adipose tissue. Acta med. scand. 177, 183-197 (1965)
9. Laurell, S., Tibbling, G.: An enzymatic fluorimetric micromethod for the determination of glycerol. Clin. chim. Acta 13, 317-322 (1968)

10. Björntorp, P., Ostman, J.: Human adipose tissue. Dynamics and regulation. Advanc. Metabolic Dis. 5, 277-327 (1971)

11. Smith, U., Sjöström, L., Björntorp, P.: Comparison between two methods to determine human adipose cell size. J. Lipid Res. 13, 822-824 (1972)

12. Goldrick, R. B.: Morphological changes in the adipocyte during fat deposition and mobilization. Amer. J. Physiol. 212, 777-782 (1967)

13. Hirsch, J., Gallian, E.: Method for the determination of adipose cell size in man and animals. J. Lipid Res. 9, 110-119 (1968)

14. Folch, J., Lees, M., Sloane Stanley, G. H.: A simple method for the isolation and purification of total lipides from animals tissues. J. biol. Chem. 226, 497-509 (1957)

15. Carlson, L. A.: Determination of serum glycerides. Acta Soc. Med. upsalien. 64, 208-213 (1959)

16. Gries, F. A., Berger, M., Neumann, M., Breiss, H., Liebermeister, H., Hesse-Wortmann, C., Jahnke, K.: Effects of norepinephrine, theofylline and dibutyryl cAMP on in vitro lipolysis on human adipose tissue in obesity. Diabetologia 8, 75-83 (1972)

17. Hall, C. L., Ball, E. G.: Factors affecting lipolysis rates in rat adipose tissue. Biochim. biophys. Acta (Amst.) 210, 209-220 (1970)

18. Burns, T. W., Langley, P.: Observations on lipolysis with isolated adipose tissue cells. J. Lab. clin. Med. 72, 813-823 (1968)

19. Gries, F. A.: Hormonal control of human adipose tissue metabolism in vitro. In: Hormone and metabolic research, suppl. 2. Adipose tissue, regulation and metabolic functions (eds. R. Levine, E. F. Pfeiffer), pp. 167-171 (1970)

20. Salans, L. B., Knittle, J. L., Hirsch, J.: The role of adipose cell size and adipose tissue insulin sensitivity in the carbohydrate intolerance of human obesity. J. clin. Invest. 47, 153-165 (1968)

21. Smith, U.: Effect of cell size on lipid synthesis by human adipose tissue in vitro. J. Lipid Res. 12, 65-70 (1971)

22. Archer, J., Gordon, P., Roth, J.: Defect in insulin binding to receptors in obese man. Amelioration with caloric restriction. J. clin. Invest. 55, 166-174 (1975)

23. Livingston, J. N., Cuatrecasas, P., Lockwood, D. H.: Insulin insensitivity of large fat cells. Science 177, 175-177 (1972)

24. Gilbert, C. H., Galton, D. J.: The effect of catecholamines and fasting on cyclic-AMP and release of glycerol from human adipose tissue. Horm. Metab. Res. 6, 229-233 (1974)

25. Fain, J. N., Kovacev, V. P., Scow, R. O.: Antilipolytic effect of insulin in isolated fat cells of the rat. Endocrinology 78, 773-778 (1966)

26. Kahn, C. R., Freychet, P., Roth, J.: Quantitative aspects of the insulin-receptor interaction in liver plasma membranes. J. biol. Chem. 249, 2249-2257 (1974)

27. Olefsky, J. M., Reaven, G. M.: Effects of age and obesity on insulin binding to isolated adipocytes. Endocrinology 96, 1486-1498 (1975)

28. Gorman, R. R., Tepperman, H. M., Tepperman, J.: Epinephrine binding and the selective restoration of adenylate cyclase activity in fat-fed rats. J. Lipid Res. 14, 279-285 (1973)

Received: September 25, 1975, and in revised form: November 27, 1975

Dr. B. Jacobsson

Dept. of Medicine II

Univ. of Gothenburg

Sahlgren's Hospital

S-41345 Gothenburg

Sweden 